\title{
Komunikasi Online Remaja dengan Orang Tuanya yang Bekerja Berperan dalam Meningkatkan Kepuasan Hidup
}

\author{
Nurul Adabina*, Eko Handayani \\ Fakultas Psikologi, Universitas Indonesia \\ e-mail: *nurul.adabina@gmail.com
}

Received: 30 th September 2021/Revised: $2^{\text {nd }}$ November 2021/Accepted: 22 ${ }^{\text {nd }}$ December 2021

\begin{abstract}
Communication with parents is one of several factors related to adolescents' life satisfaction. Parental work pressures that hinder parents from communicating with adolescents can be reduced through online communication. The purpose of this research was to examine the role of online parent-child communication in life satisfaction among adolescents with working parents. A total of 106 adolescents aged 10-15 years with working parents participated in this research. Parent-child online communication was measured using a modified version of Online Parent-Child Communication, while Life Satisfaction was measured using the Satisfaction with Life Scale Adapted for Children. The results showed parent-child online communication had a significant and positive effect on life satisfaction among adolescents with working parents. In addition, this research also found a significant and positive effect between parent-child online communication and life satisfaction of male and female adolescents with working parents. Therefore, parents should optimize online communication with their adolescents when they are working because online communication gives an impression of parental support, which contributes to increasing adolescents' life satisfaction.
\end{abstract}

Keywords: life satisfaction; online parent-child communication, adolescents, working parents

Abstrak. Salah satu faktor yang mempengaruhi kepuasan hidup remaja adalah komunikasi dengan orang tua. Tuntutan pekerjaan yang seringkali menyulitkan orang tua untuk berkomunikasi dengan remaja dapat diminimalisir dengan komunikasi online. Penelitian ini bertujuan untuk mengetahui pengaruh komunikasi online orang tua-anak terhadap kepuasan hidup remaja dengan kedua orang tua bekerja. Partisipan terdiri dari 106 remaja berusia 10-15 tahun dengan kedua orang tua bekerja. Komunikasi online orang tua-anak diukur menggunakan instrumen hasil modifikasi alat ukur Online Parent-Child, sedangkan Satisfaction with Life Scale Adapted for Children digunakan untuk mengukur kepuasan hidup. Hasil penelitian menemukan adanya pengaruh yang signifikan dari komunikasi online orang tua-anak terhadap kepuasan hidup remaja yang memiliki orang tua bekerja. Selain itu, hasil yang sama juga ditemukan pada remaja laki-laki dan perempuan yang memiliki kedua orang tua bekerja. Orang tua perlu memaksimalkan komunikasi online dengan remaja selama berada di tempat kerja karena komunikasi online memberikan kesan bahwa orang tua mendukung mereka, sehingga dapat meningkatkan kepuasan hidup remaja.

Kata kunci: kepuasan hidup, komunikasi online orang tua-anak, remaja, orang tua bekerja 
Kepuasan hidup merupakan salah satu konstruk penting yang berhubungan erat dengan kebahagiaan serta hasil-hasil positif pada aspek perilaku, psikologis, dan individu (Oberle et al., 2011). Kepuasan hidup pada remaja perlu menjadi perhatian karena kepuasan hidup cenderung mengalami penurunan saat seseorang mengawali masa remaja (Weber et al. 2013). Penurunan kepuasan hidup ini disebabkan perubahan fisik, kognisi, emosi, perilaku, dan sosial yang memengaruhi bagaimana remaja menilai kepuasan hidup mereka (Moksnes \& Espnes, 2013; Žukauskienė, 2014). Kepuasan hidup yang menurun di masa remaja juga dapat dijelaskan oleh meningkatnya tekanan akademis seiring transisi dari jenjang pendidikan dasar ke pendidikan menengah. Jenjang pendidikan menengah ditandai dengan standar kurikulum yang lebih tinggi dan penilaian performa yang lebih sering dan kompleks (Liu et al., 2015). Tingkat kepuasan hidup yang tinggi pada remaja berperan dalam melindungi remaja dari berbagai tekanan, seperti tekanan sosial. Remaja dengan kepuasan hidup yang tinggi memiliki fisik yang lebih sehat, relasi sosial yang lebih baik, aktif mengikuti lebih banyak kegiatan, serta memiliki prestasi dan performa akademik yang lebih optimal (Proctor et al., 2017).

Penelitian terdahulu telah menunjukkan bahwa kepuasan hidup dipengaruhi oleh gender. Studi yang dilakukan oleh Moksnes dan Espnes (2013) menemukan bahwa remaja laki-laki memiliki skor kepuasan hidup yang lebih tinggi dibandingkan remaja perempuan. Gender menjadi korelasi yang penting bagi kepuasan hidup remaja karena meningkatnya perbedaan antar gender pada masa remaja seiring dengan terjadinya perubahan fisik dan hormonal. Pada studi dengan responden remaja di Cina, remaja laki-laki ditemukan memiliki kepuasan hidup yang lebih tinggi. Kebudayaan di Cina cenderung masih menjunjung hierarki gender yang lebih menguntungkan bagi remaja laki-laki, sehingga remaja laki-laki memiliki lebih banyak hak istimewa dan cenderung berada di posisi yang lebih diuntungkan (Ye et al., 2013).

Tidak hanya gender dan faktor demografi secara umum, kepuasan hidup remaja juga dipengaruhi oleh faktor intrapersonal, faktor kesehatan fisik, faktor hubungan dengan keluarga, faktor lingkungan, faktor pendidikan, serta pengaruh sosiokultural (Proctor et al., 2017). Faktor keluarga yang mendukung kepuasan hidup 


\section{ADABINA \& HANDAYANI}

remaja mencakup gaya pengasuhan orang tua yang autoritatif, dukungan emosional dan sosial dari orang tua, konflik keluarga yang minim, dan kualitas lingkungan fisik yang optimal (Proctor et al., 2017). Kajian literatur yang dilakukan oleh Soares et al. (2019) menyimpulkan bahwa dukungan keluarga dan orang tua menyumbangkan proporsi terbesar bagi kepuasan hidup remaja. Komunikasi yang baik dengan orang tua membantu remaja mengekspresikan ide dan perasaan mereka secara lebih terbuka. Hal ini diinterpretasikan remaja sebagai bentuk kedekatan, kepercayaan, dan dukungan orang tua (Cava et al., 2014).

Komunikasi yang tidak terjalin baik dengan orang tua akan memunculkan perasaan tidak dipahami pada remaja. Perasaan tidak dipahami oleh orang tua menurunkan kepuasan remaja terhadap keluarga, yang cenderung menurunkan kepuasan hidup global (Nickerson \& Nagle, 2004). Komunikasi antara orang tua dan remaja juga penting bagi hubungan mereka yang sedang mengalami perubahan saat anak memasuki usia remaja. Di satu sisi, remaja masih merasakan adanya ketergantungan dengan orang tua, sekaligus mulai ingin lebih mandiri. Begitupun sebaliknya, orang tua ingin remaja mereka untuk mandiri, namun seringkali sulit untuk melepaskan anak-anak mereka (Papalia \& Martorell, 2014). Selama penataan kembali hubungan antara orang tua dan anak yang beranjak remaja, diperlukan cara berkomunikasi yang memfasilitasi kebutuhan remaja akan otonomi dan kemandirian, sekaligus meningkatkan keterhubungan dan keterkaitan antara remaja dan orang tua (Keijsers \& Poulin, 2013).

Masa remaja merupakan masa transisi yang memengaruhi aspek hubungan orang tua dan anak. Keinginan atas otonomi yang meningkat saat remaja menghadirkan tantangan komunikasi bagi orang tua-anak (Sillars et al., 2014). Terlepas dari kuatnya keterikatan emosi antara orang tua dengan remaja, remaja mulai menjaga privasi dan membatasi hal-hal yang mereka komunikasikan dengan orang tua. Hal ini akan memengaruhi frekuensi komunikasi orang tua dan anak yang beranjak remaja (Laursen \& Collins, 2003; Dworkin et al., 2019). Frekuensi komunikasi antara orang tua dan remaja perlu diperhatikan karena adanya diskrepansi antara persepsi orang tua dan remaja mengenai kuantitas komunikasi mereka. Orang tua sudah merasa sudah 
cukup sering menjalin komunikasi dengan remaja, sedangkan remaja merasa frekuensi tersebut masih belum cukup sering (DeBoer et al., 2017).

Berdasarkan paparan di atas, komunikasi yang terjalin dengan baik dan terjadi secara sering antara orang tua dan remaja memiliki pengaruh terhadap penilaian kepuasan hidup pada remaja. Studi pada remaja di Indonesia menemukan bahwa komunikasi secara langsung dengan orang tua telah terbukti berhubungan dengan kepuasan hidup (Susanti, 2013). Kendati demikian, tidak semua orang tua memiliki kesempatan yang sama untuk menjalin komunikasi dengan remaja. Beberapa orang tua menemui tantangan untuk menjaga komunikasi dengan remaja mereka, salah satunya pada keluarga dengan orang tua bekerja.

Kondisi pekerjaan orang tua meningkatkan kompleksitas mereka dalam mengatur kehidupan dalam keluarga, memenuhi peran sebagai orang tua, serta memengaruhi dinamika hubungan mereka dengan remaja (Tulk et al., 2016 \& Vieira et al., 2016). Orang tua bekerja rentan merasakan beban berlebih karena tanggung jawab di rumah disertai dengan tambahan beban di lingkungan kerja (McQuillan \& Bates, 2017). Saat merasakan beban berlebih, orang tua rentan mengalami stress, menunjukkan penerimaan yang rendah terhadap remaja, dan terlibat konflik dengan remaja. Konflik dengan orang tua cenderung menurunkan kepuasan hidup remaja (Chappel et al., 2014). Poire (2005) menyatakan bahwa kedua orang tua bekerja juga rentan mengalami role strain, suatu kondisi saat seseorang merasa tidak nyaman akan peran-peran yang mereka jalani dan kesulitan untuk menyesuaikan tingkah laku dengan berbagai peran tersebut. Orang tua yang mengalami role strain kesulitan untuk berperilaku dan berkomunikasi dengan remaja (Poire, 2005).

Beberapa penelitian telah menemukan bahwa pekerjaan orang tua rentan menghadirkan masalah bagi komunikasi mereka dengan remaja. Kendati demikian, permasalahan komunikasi saat orang tua berada di tempat kerja mungkin dapat diatasi dengan komunikasi online. Komunikasi online merujuk pada penggunaan berbagai bentuk komunikasi yang dilakukan dengan perantara sistem komputer, seperti surat elektronik, pesan singkat, ruang obrolan, aplikasi media sosial. Selain komunikasi tekstual komunikasi online juga memfasilitasi obrolan suara dengan 


\section{ADABINA \& HANDAYANI}

panggilan telepon, konferensi video, dan kamera web (Chan, 2020). Komunikasi online juga dapat didefinisikan sebagai penggunaan perangkat komunikasi dan media sosial yang tersedia dalam berbagai format, seperti pesan singkat, surat elektronik, situs-situs seperti Facebook, dan layanan konferensi video seperti Skype (Rudi et al., 2015).

Jumlah remaja yang menggunakan komunikasi online sangat tinggi, bahkan jauh lebih tinggi dibandingkan orang dewasa (Valkenburg \& Peter, 2011). Remaja menggunakan komunikasi online untuk terhubung dengan keluarga dan teman-teman, saling berbagi gambar, dan bertukar informasi (O'Keeffe \& Clarke-Pearson, 2011). Studi yang dilakukan oleh Ang (2017) menemukan bahwa penggunaan internet untuk berkomunikasi menunjukkan frekuensi yang lebih tinggi pada remaja perempuan di Malaysia. Hal ini disebabkan adanya kebutuhan yang lebih tinggi pada remaja perempuan untuk menjaga hubungan yang sudah terjalin di dunia nyata (Ang, 2017).

Komunikasi online telah menjadi bagian integral bagi komunikasi antara orang tua dan remaja. Bagi orang tua, komunikasi online membantu mereka menjalankan peran dan tanggung jawab mereka sesuai dengan tahapan perkembangan anak, terutama berkomunikasi dengan anak yang beranjak remaja (Rudi et al., 2015). Hertlein \& Blumer (2014) telah menemukan bahwa alih-alih menggantikan interaksi tatap muka, komunikasi online justru mempererat hubungan keluarga karena dapat menawarkan pola komunikasi baru bagi orang tua dan remaja. Pola komunikasi baru ini menjadi cara orang tua beradaptasi dengan kedewasaan dan keinginan atas otonomi yang meningkat pada remaja (Rudi et al., 2015). Pemanfaatan komunikasi online memungkinkan remaja memperoleh independensi dalam komunikasi, sekaligus memastikan interaksi dengan orang tua tetap terjalin (Carvalho et al., 2015; PadillaWalker, 2012)

Bagi remaja yang memiliki orang tua bekerja, penggunaan komunikasi online membantu mereka untuk terhubung dengan orang tua yang berada di tempat kerja (Christensen, 2009). Komunikasi online juga menjadi pelengkap komunikasi tatap muka karena memberikan kesan bahwa orang tua hadir dan menjalin komunikasi dengan remaja saat berada di jarak yang jauh. Kehadiran jarak jauh orang tua berkontribusi terhadap ikatan yang kuat antara orang tua dan anak, serta menjadi 
kompromi bagi elemen-elemen pengasuhan orang tua, serta penyedia rasa aman bagi remaja (Christensen, 2009).

Penelitian Niu et al. (2019) menemukan adanya hubungan positif antara komunikasi online dengan kepuasan hidup remaja pada keluarga pekerja migran. Komunikasi online berperan sebagai kompensasi dan pelengkap komunikasi tatap muka antara orang tua pekerja migran dan remaja. Dengan tetap berkomunikasi secara online, anak dengan orang tua pekerja migran merasakan adanya keterhubungan dengan orang tua mereka (Madianou \& Miller, 2011). Komunikasi online yang positif dengan orang tua yang dinas di wilayah jauh berhubungan dengan keberfungsian yang lebih baik pada remaja dari keluarga militer (Friedman et al., 2017). Komunikasi online juga dimanfaatkan orang tua yang bekerja sebagai mobile workers. Pekerjaan ini menuntut mereka untuk bekerja dengan jarak yang cukup jauh dari rumah untuk beberapa waktu tertentu, seperti pekerja di bisnis perjalanan (Abel et al., 2020).

Komunikasi online telah terbukti berpengaruh terhadap kepuasan hidup remaja dari keluarga yang terpisah secara geografis. Meskipun penelitian ini berfokus pada remaja dan orang tua yang masih bertempat tinggal di rumah yang sama, komunikasi secara langsung tidak bisa terjalin ketika kedua orang tua sedang berada di tempat kerja. Hal ini perlu menjadi perhatian karena angka penduduk bekerja yang berada dalam status kawin tergolong tinggi. Menurut data Kementerian Pemberdayaan Perempuan dan Perlindungan Anak pada tahun 2017, sejumlah 71,49\% dari total penduduk perempuan bekerja dan $76,39 \%$ dari total penduduk laki-laki bekerja berstatus kawin (Kementerian Pemberdayaan Perempuan dan Perlindungan Anak, 2018). Meskipun tidak tersedia data orang tua bekerja, tingginya jumlah penduduk bekerja di Indonesia berstatus kawin diasumsikan dapat menjadi gambaran jumlah orang tua bekerja. Bagi keluarga dengan orang tua pekerja penuh waktu (full time workers), komunikasi online memungkinkan terjalinnya komunikasi antara remaja dan orang tua (Christensen, 2009). Komunikasi online memberikan kesan bahwa orang tua hadir, meskipun sedang berada di jarak yang jauh. 


\section{ADABINA \& HANDAYANI}

Peraturan untuk kembali bekerja dari kantor berdampak bagi dinamika di dalam keluarga. Orang tua yang tadinya bekerja dari rumah dan bisa mendampingi anak bersekolah dari rumah, kini harus melakukan penyesuaian kembali terkait sistem sekolah jarak jauh anak (Satriawan, 2020). Maka dari itu, komunikasi online semakin diperlukan karena orang tua perlu membantu anak-anak mereka bersekolah dari rumah, sementara mereka berada di tempat kerja.

Penelitian ini bertujuan untuk meneliti apakah terdapat pengaruh komunikasi online orang tua-anak terhadap kepuasan hidup remaja yang memiliki kedua orang tua bekerja. Terdapat perbedaan antara penelitian ini dengan penelitian Niu et al. (2019). Pada studinya, Niu et al. (2019) meneliti pengaruh komunikasi online orang tua-anak terhadap kepuasan hidup remaja dari keluarga pekerja migran. Di sisi lain, penelitian kali ini berfokus pada remaja dengan kedua orang tua bekerja. Meskipun tidak berpisah jauh secara geografis seperti keluarga pekerja migran, keluarga dengan orang tua bekerja juga mengalami tantangan komunikasi saat orang tua berada di tempat kerja. Hal ini dapat memengaruhi penilaian kepuasan hidup remaja.

Penelitian ini juga melihat apakah komunikasi online orang tua-anak berpengaruh terhadap kepuasan hidup remaja laki-laki dan remaja perempuan. Hal ini didasarkan hasil penelitian Ang (2017) yang menemukan frekuensi lebih tinggi pada komunikasi online remaja perempuan. Frekuensi yang lebih tinggi pada pemanfaatan komunikasi online remaja perempuan disebabkan adanya keinginan yang kuat untuk menjaga kerekatan hubungan yang dimiliki di dunia nyata (Ang, 2017). Keinginan yang kuat ini meluas ke jejaring komunikasi online yang memberikan kemudahan untuk tetap terhubung dengan relasi dunia nyata (Wohn, 2012). Selain itu, usia pubertas yang lebih awal pada remaja perempuan juga memengaruhi intensitas penggunaan komunikasi online. Kematangan akibat pubertas mendorong remaja perempuan untuk mengekspresikan dirinya secara online lebih dahulu dibandingkan remaja laki-laki (Valkenburg et al., 2011). Perbedaan pola komunikasi online antara remaja laki-laki dan remaja perempuan ini bisa memengaruhi komunikasi online orang tua-anak dan kepuasan hidup remaja. 


\section{Metode}

\section{Partisipan Penelitian}

Partisipan penelitian adalah remaja laki-laki dan perempuan berusia 10-15 tahun, memiliki kedua orang tua yang bekerja, dan memiliki akses Internet. Sejumlah 106 partisipan direkrut menggunakan teknik purposive sampling dengan metode homogenous sampling, yakni metode sampling yang berfokus pada kandidat partisipan yang memiliki sifat yang mirip atau karakteristik-karakteristik tertentu (Etikan et al., 2016).

\section{Prosedur Penelitian}

Pengambilan data dilakukan secara online pada 18 Mei hingga 16 Juni 2020. Peneliti menyebarkan kuesioner secara online melalui aplikasi media sosial, seperti WhatsApp, LINE, dan Twitter. Di dalam penyebaran kuesioner, peneliti mencantumkan poster dan sebaran digital yang berisi informasi mengenai penelitian yang mencakup syarat partisipan, estimasi waktu pengerjaan kuesioner penelitian, kontak peneliti, serta tautan kuesioner penelitian. Kuesioner penelitian mencakup informasi singkat mengenai penelitian, yang dilanjutkan dengan informed consent atau lembar persetujuan untuk dibaca oleh orang tua atau wali partisipan. Apabila orang tua atau wali memberikan izin kepada remaja untuk menjadi partisipan dalam penelitian, maka mereka memilih opsi 'bersedia'. Setelah itu, terdapat lembar persetujuan untuk dibaca oleh partisipan untuk selanjutnya memilih opsi 'bersedia' jika berkenan untuk menjadi partisipan dalam penelitian. Setelah lembar informed consent, link penelitian berisi instrumen penelitian dan pengisian data demografis.

\section{Instrumen Penelitian}

Kepuasan hidup remaja diukur menggunakan Satisfaction with Life Scale Adapted for Children (SWLS-C) yang dikembangkan oleh Gadermann et al. (2010). Instrumen ini terdiri dari 5 item, dengan beberapa contoh item yaitu: (1) Hal-hal dalam hidup saya berjalan sangat baik; dan (2) Saya bahagia dengan hidup saya. Jawaban partisipan diberikan melalui skala Likert 5-poin, dimulai dari sangat tidak setuju hingga sangat 


\section{ADABINA \& HANDAYANI}

setuju. Alat ukur SWLS-C yang digunakan dalam penelitian ini melalui proses adaptasi ke dalam bahasa Indonesia. Alat ukur SWLS-C melalui tahapan uji coba secara online kepada 228 remaja berusia 10-15 tahun untuk mengetahui reliabilitas dan validitas alat ukur. Berdasarkan hasil pengujian reliabilitas ditemukan nilai Coefficient Alpha sebesar $\alpha=0.774$.

Komunikasi online orang tua-anak diukur menggunakan modifikasi dari kuesioner Online Parent-Child Communication (Niu et al., 2019). Instrumen ini terdiri dari 5 item kuantitatif dan 3 item kualitatif. Item kuantitatif mengukur frekuensi komunikasi orang tua dengan anak secara online melalui pesan singkat, media sosial, panggilan suara, panggilan video, dan surat elektronik dengan salah satu contoh item

yaitu: (1) Seberapa sering kamu berkomunikasi atau berinteraksi dengan orang tua di media sosial? (Contoh: Facebook, Instagram). Kelima item diberi respons menggunakan skala Likert 5-poin, dimulai dari "tidak pernah" hingga "selalu". Item kualitatif berbentuk pertanyaan untuk mengetahui aplikasi yang paling sering digunakan partisipan untuk berkomunikasi dengan orang tua mereka secara online. Salah satu contoh item yaitu: "Dari semua aplikasi yang disebutkan di atas, yang paling sering kamu gunakan adalah...". Alat ukur ini melalui tahapan uji coba secara online kepada 39 remaja berusia 10-15 tahun untuk mengetahui reliabilitas dan validitas alat ukur. Hasil pengujian reliabilitas menunjukkan nilai Coefficient Alpha sebesar $\alpha=0.712$.

\section{Analisis Data}

Peneliti menggunakan SPSS untuk melakukan analisis statistik deskriptif guna mengetahui gambaran umum partisipan dan variabel penelitian mencakup mean, standar deviasi, serta reliabilitas yang akan dilakukan menggunakan teknik Cronbach's Alpha. Analisis regresi sederhana digunakan untuk mengetahui kontribusi komunikasi online orang tua-anak terhadap kepuasan hidup remaja yang memiliki kedua orang tua bekerja. 
VOLUME 5, NOMOR 2, 2021: 174-192

\section{Hasil}

\section{Data Deskriptif}

Penelitian ini diikuti oleh 106 responden yang didominasi oleh partisipan perempuan (56,6\%). Berdasarkan jenjang pendidikan, sebagian besar responden adalah siswa SMP (57,5\%). Tabel 1 menggambarkan data demografi partisipan.

Tabel 1.

Data Demografi Responden (N=106)

\begin{tabular}{lccc}
\hline Karakteristik & $\mathbf{n}$ & $\mathbf{\%}$ & Total \\
\hline Jenis Kelamin & & & \\
Laki-laki & 46 & 43,4 & $106(100 \%)$ \\
Perempuan & 60 & 56,6 & \\
Jenjang Pendidikan & & & \multirow{2}{*}{$106(100 \%)$} \\
SD & 34 & 32,1 & \\
SMP & 61 & 57,5 & \\
SMA & 11 & 10,4 & \\
Pekerjaan Ayah & & & \multirow{2}{*}{$106(100 \%)$} \\
Swasta & 45 & 42,5 & \\
ASN \& BUMN & 25 & 23,6 & \\
Wiraswasta & 11 & 10,4 & \\
Profesional & 10 & 9,4 & \\
Anggota TNI/Polri & 6 & 5,7 & \\
Teknisi dan Asisten Tenaga Profesional & 4 & 3,8 & \\
Manajerial & 2 & 1,9 & \\
Tenaga Tata Usaha & 2 & 1,9 & \\
Pekerja Kasar & 1 & 0,9 & \\
Pekerjaan Ibu & & & \\
ASN \& BUMN & 37 & 34,9 & $106(100 \%)$ \\
Swasta & 35 & 33,0 & \\
Profesional & 24 & 22,6 & \\
Wiraswasta & 6 & 5,7 & \\
Teknisi dan Asisten Tenaga Profesional & 3 & 2,8 & \\
Tenaga Tata Usaha & 1 & 0,9 & \\
\hline
\end{tabular}

\section{Uji Hipotesis}

Berikut adalah hasil analisis regresi sederhana komunikasi online orang tuaanak dan kepuasan hidup remaja yang memiliki orang tua bekerja. 
ADABINA \& HANDAYANI

Tabel 2.

Kontribusi Komunikasi Online Orang Tua-Anak terhadap Kepuasan Hidup Remaja

\begin{tabular}{lcccc}
\hline \multicolumn{1}{c}{ Variabel Prediktor } & $\boldsymbol{R}$ & $\boldsymbol{R}^{\mathbf{2}}$ & $\mathbf{B}$ & $\mathbf{F}$ \\
\hline Komunikasi Online Orang Tua-Anak & 0,308 & 0,095 & $0,361^{* *}$ & 10,931 \\
\hline${ }^{* *} p<0,01$ & & & &
\end{tabular}

Berdasarkan uji hipotesis tahap pertama, komunikasi online orang tua-anak memberikan pengaruh terhadap kepuasan hidup remaja yang memiliki kedua orang tua bekerja $\left(\mathrm{R}^{2}=0,095, \mathrm{~F}(1,104)=10,931, \mathrm{~B}=0,361, p<0,01\right)$. Hasil tersebut menunjukkan adanya 9,5\% varians dari kepuasan hidup remaja dapat diprediksi oleh komunikasi online yang mereka jalin dengan orang tua, sedangkan 90,5\% kepuasan hidup remaja diprediksi oleh faktor lainnya. Proporsi tersebut termasuk ke dalam kategori small effect (Hemphill dalam Gignac \& Szodorai, 2016). Arah hubungan yang positif menunjukkan bahwa meningkatnya komunikasi online dengan orang tua, semakin tinggi pula tingkat kepuasan hidup pada remaja.

\section{Tabel 3.}

Kontribusi Komunikasi Online Orang Tua-Anak terhadap Kepuasan Hidup Remaja Laki-laki

\begin{tabular}{lcccc}
\hline \multicolumn{1}{c}{ Variabel Prediktor } & $\boldsymbol{R}$ & $\boldsymbol{R}^{\mathbf{2}}$ & $\mathbf{B}$ & $\mathbf{F}$ \\
\hline Komunikasi Online Orang Tua-Anak & 0,448 & 0,201 & $0,574^{*}$ & 11,050 \\
\hline${ }^{*} p<0,05$ & & & &
\end{tabular}

Tabel 3 berisi hasil analisis regresi sederhana untuk memprediksi kepuasan hidup remaja dari komunikasi online orang tua-anak pada partisipan laki-laki. Pada partisipan laki-laki, komunikasi online dengan orang tua menjelaskan proporsi yang signifikan dan positif dari varians kepuasan hidup $\left(R^{2}=0,201, F(1,44)=11,050, B=\right.$ 0,574, $p<0,05)$. Hasil tersebut menunjukkan adanya kontribusi sebesar 20,1\% dari kepuasan hidup remaja laki-laki yang dapat diprediksi oleh komunikasi online mereka dengan orang tua. Proporsi tersebut termasuk ke dalam medium effect (Hemphill dalam Gignac \& Szodorai, 2016). Arah hubungan yang positif menunjukkan bahwa semakin 
meningkatnya komunikasi online dengan orang tua, semakin tinggi pula tingkat kepuasan hidup pada remaja laki-laki.

\section{Tabel 4.}

Kontribusi Komunikasi Online Orang Tua-Anak terhadap Kepuasan Hidup Remaja Perempuan

\begin{tabular}{lcccc}
\hline \multicolumn{1}{c}{ Variabel Prediktor } & $\mathbf{R}$ & $\mathbf{R}^{2}$ & $\mathbf{B}$ & $\mathbf{F}$ \\
\hline Komunikasi Online Orang Tua-Anak & 0,257 & 0,066 & $* 0,285$ & 4,107 \\
\hline${ }^{*} p<0,05$ & & & &
\end{tabular}

Tabel 4 berisi hasil analisis regresi sederhana untuk memprediksi kepuasan hidup remaja dari komunikasi online orang tua-anak pada partisipan perempuan. Komunikasi online dengan orang tua menjelaskan proporsi yang signifikan dan positif dari varians kepuasan hidup pada partisipan perempuan $\left(\mathrm{R}^{2}=0,066, \mathrm{~F}(1,58)=4,107\right.$, $\mathrm{B}$ $=0,285, p<0,05)$. Hasil tersebut menunjukkan adanya sumbangan sebesar $6,6 \%$ dari kepuasan hidup remaja perempuan yang dapat diprediksi oleh komunikasi online mereka dengan orang tua. Proporsi tersebut dikategorikan sebagai small effect (Hemphill dalam Gignac \& Szodorai, 2016). Arah hubungan yang positif mengindikasikan meningkatnya komunikasi online dengan orang tua, semakin tinggi pula tingkat kepuasan hidup pada remaja perempuan.

\section{Diskusi}

Berdasarkan hasil analisis, komunikasi online antara orang tua-anak berpengaruh signifikan terhadap kepuasan hidup remaja. Hasil ini menunjukkan bahwa komunikasi online orang tua-anak menjelaskan proporsi varians yang signifikan dari kepuasan hidup. Sejalan dengan temuan ini, Niu et al. (2019) menemukan bahwa komunikasi online orang tua dan anak berhubungan dengan kepuasan hidup. Niu et al. (2019) menjelaskan bahwa komunikasi online merupakan pelengkap komunikasi offline dan menjadi keuntungan bagi komunikasi jarak jauh. Dalam hal ini, komunikasi online merupakan kompensasi dari berkurangnya komunikasi antara remaja dan orang tua yang bekerja. 


\section{ADABINA \& HANDAYANI}

Hasil ini juga sesuai dengan penelitian oleh Coyne et al. (2014) yang menyatakan bahwa komunikasi online di dalam keluarga akan meningkatkan keterhubungan antara remaja dan orang tua. Penggunaan moda komunikasi online bisa menjadi bagian dari interaksi keluarga dan memperkuat hubungan keluarga. Selain meningkatkan komunikasi anak dan orang tua, penggunaan komunikasi online juga bisa digunakan untuk hal lain, seperti saling memberikan komentar positif di foto profil atau status masing-masing. Hal ini merekatkan hubungan antara orang tua dan remaja. Hubungan yang baik dengan orang tua merupakan faktor yang memprediksi kepuasan hidup remaja (Proctor et al., 2017).

Kontribusi komunikasi online orang tua-anak terhadap kepuasan hidup remaja juga dapat dijelaskan oleh studi Rudi et al. (2015). Studi tersebut menemukan bahwa penggunaan komunikasi online di dalam keluarga meningkat seiring bertambahnya usia anak dan mencapai puncaknya saat anak memasuki usia remaja. Komunikasi online memiliki peran yang signifikan bagi orang tua untuk tetap terkoneksi dengan remaja, terlepas dari meningkatnya otonomi yang diperoleh remaja (Rudi et al., 2015).

Peran komunikasi online orang tua-anak terhadap kepuasan hidup remaja dengan orang tua bekerja juga dapat dijelaskan oleh penelitian Christensen (2009). Penelitian tersebut menyatakan bahwa komunikasi online menjadi pelengkap komunikasi tatap muka antara remaja dan orang tua bekerja. Komunikasi online memberikan kesan bahwa orang tua hadir dan menjalin komunikasi dengan remaja, meskipun sedang berada di jarak yang jauh. Komunikasi tatap muka dengan orang tua telah terbukti berhubungan dengan kepuasan hidup pada remaja, termasuk di Indonesia (Susanti, 2013).

Berdasarkan hasil penelitian, komunikasi online orang tua-anak berkontribusi terhadap kepuasan hidup yang tergolong tinggi pada remaja. Hasil ini dapat dijelaskan oleh penelitian Kinkead et al. (2017) yang menyatakan bahwa remaja tidak merasakan ketegangan dan konflik orang tua terkait keluarga dan pekerjaan. Hal tersebut disebabkan remaja menyadari adanya usaha dari orang tua untuk menjaga kesejahteraan anggota keluarga termasuk anak, terlepas dari tantangan yang hadir 
akibat pekerjaan mereka. Komunikasi online antara orang tua-anak dinilai sebagai salah satu cara orang tua untuk menjaga kesejahteraan keluarga.

Temuan kedua dari penelitian ini adalah kontribusi dari komunikasi online antara orang tua-anak terhadap kepuasan hidup remaja laki-laki dan remaja perempuan. Hasil ini mendukung temuan beberapa studi yang menemukan bahwa komunikasi dengan orang tua berhubungan dengan kepuasan hidup yang tinggi pada remaja laki-laki dan remaja perempuan (Levin et al., 2012; Cava et al., 2014). Remaja menilai komunikasi yang baik dengan orang tua sebagai cara untuk menyampaikan perasaan dan pemikiran secara lebih terbuka di dalam keluarga. Remaja menginterpretasikan komunikasi yang terjalin dengan baik di dalam keluarga sebagai bentuk kedekatan, dukungan, dan kepercayaan dari orang tua. Meskipun otonomi yang meningkat di masa remaja mendorong mereka untuk membahas beberapa topik tertentu dengan teman, mereka masih menilai komunikasi dengan orang tua sebagai hal yang penting (Cava et al., 2014).

Adanya pengaruh dari komunikasi online antara orang tua-anak terhadap kepuasan hidup remaja laki-laki dan perempuan juga dapat dijelaskan oleh frekuensi yang tinggi dalam pemanfaatan komunikasi online remaja laki-laki dan perempuan. Penelitian Bonetti et al. (2010) menemukan frekuensi komunikasi online digunakan secara setara antara remaja laki-laki dan remaja perempuan. Selain untuk berkomunikasi online dengan orang tua, remaja perempuan menggunakan komunikasi online untuk bermedia sosial, memperkuat persahabatan dunia nyata, dan menjembatani hubungan dengan teman yang jarang mereka temui. Sedangkan, remaja laki-laki memanfaatkan komunikasi online untuk mencari teman baru, mengeksplorasi kemungkinan kencan, dan berkomunikasi dengan orang asing (Bonetti et al., 2010; Borca et al., 2015)

Temuan penelitian ini juga mengonfirmasi hasil penelitian Mesch (2016) yang menemukan proporsi komunikasi online dengan orang tua yang setara antara remaja laki-laki dan perempuan. Berkomunikasi secara online dengan remaja menjadi cara baru bagi orang tua untuk tetap terhubung dengan remaja, sekaligus memberikan ruang bagi remaja beradaptasi dengan otonomi yang meningkat (Rudi et al., 2015). 
Coyne et al. (2014) menemukan bahwa komunikasi online dengan orang tua meningkatkan perasaan terhubung antara remaja dengan orang tua. Perasaan terhubung antara orang tua dan remaja akan meningkatkan subjective well-being, yang juga mencakup kepuasan hidup.

Meskipun penelitian terdahulu melaporkan bahwa remaja perempuan lebih terbuka dalam berkomunikasi dengan orang tua daripada remaja laki-laki (Bireda \& Pillay, 2017), hasil penelitian ini menunjukkan proporsi varians kepuasan hidup yang lebih kecil pada remaja perempuan. Hal ini berkaitan dengan perbedaan orientasi dalam komunikasi antara kedua gender, di mana perempuan umumnya lebih mengutamakan ekspresi emosi dan intimasi dalam berkomunikasi (McNaughton, 2000), sehingga ketika melakukan komunikasi online, kebutuhan terhadap kondisi tersebut menjadi sulit untuk dipenuhi. Hal ini diasumsikan menjadi penyebab lebih rendahnya kontribusi komunikasi online pada remaja perempuan terhadap kepuasan hidup dibandingkan remaja-laki-laki. Temuan ini dapat menjadi pertimbangan untuk penelitian selanjutnya.

\section{Kesimpulan}

Penelitian ini bertujuan untuk melihat pengaruh komunikasi online remaja dengan orang tua yang bekerja terhadap kepuasan hidupnya. Hasil analisis menunjukkan bahwa komunikasi online orang tua-anak memiliki kontribusi yang signifikan terhadap kepuasan hidup remaja yang memiliki kedua orang tua bekerja. Selain itu, kontribusi komunikasi online terhadap kepuasan hidup ditemukan lebih besar pada remaja laki-laki dibandingkan dengan remaja perempuan. Penelitian ini diharapkan dapat menggambarkan pentingnya komunikasi online antara remaja dengan orang tua, serta memperluas pengetahuan dalam bidang psikologi perkembangan, khususnya berkaitan dengan kepuasan hidup remaja. 


\section{Daftar Pustaka}

Abel, S., Machin, T., \& Brownlow, C. (2020). Social media, rituals, and long-distance family relationship maintenance: A mixed-methods systematic review. New Media \& Society, 1461444820958717. https://doi.org/10.1177/1461444820958717.

Ang, C. S. (2017). Internet habit strength and online communication: Exploring gender differences. Computers in Human Behavior, 66, 1-6. https://doi:10.1016/j.chb.2016.09.028.

Bireda, A. D., \& Pillay, J. (2018). Perceived parent-child communication and well-being among Ethiopian adolescents. International Journal of Adolescence and Youth, 23(1). https://doi.org/10.1080/02673843.2017.1299016.

Bonetti, L., Campbell, M. A., \& Gilmore, L. (2010). The relationship of loneliness and social anxiety with children's and adolescents' online communication. Cyberpsychology, Behavior, and Social Networking, 13(3), 279-285. https://doi:10.1089/cyber.2009.0215.

Borca, G., Bina, M., Keller, P. S., Gilbert, L. R., \& Begotti, T. (2015). Internet use and developmental tasks: Adolescents' point of view. Computers in Human Behavior, 52, 49-58. https://doi.org/10.1016/j.chb.2015.05.029.

Carvalho, J., Francisco, R., \& Relvas, A. P. (2015). Family functioning and information and communication technologies: How do they relate? A literature review. Computers in Human Behavior, 45, 99-108. https://doi.org/10.1016/j.chb.2014.11.037.

Cava, M. J., Buelga, S., \& Musitu, G. (2014). Parental communication and life satisfaction in adolescence. The Spanish Journal of Psychology, 17. https://doi:10.1017/sjp.2014.107.

Chan, G. H. (2020). Intimacy, friendship, and forms of online communication among Hidden Youth in Hong Kong. Computers in Human Behavior, 111, 106407. https://doi.org/10.1016/j.chb.2020.106407.

Chappel, A. M., Suldo, S. M., \& Ogg, J. A. (2014). Associations between adolescents' family stressors and life satisfaction. Journal of child and family Studies, 23(1), 76-84. https://doi:10.1007/s10826-012-9687-9.

Christensen, T. H. (2009). 'Connected presence' in distributed family life. New Media $\mathcal{E}$ Society, 11(3), 433-451. https://doi.org/10.1177/1461444808101620.

Coyne, S. M., Padilla-Walker, L. M., Day, R. D., Harper, J., \& Stockdale, L. (2014). A friend request from dear old dad: Associations between parent-child social networking and adolescent outcomes. Cyberpsychology, Behavior, and Social Networking, 17(1), 8-13. https://doi:10.1089/cyber.2012.0623.

DeBoer, M. D., Valdez, R., Chernavvsky, D. R., Grover, M., Solorzano, C. B., Herbert, K., \& Patek, S. (2017). The impact of frequency and tone of parent-youth communication on type 1 diabetes management. Diabetes Therapy, 8(3), 625-636. https://doi:10.1007/s13300-017-0259-2.

Dworkin, J., Hessel, H., \& LeBouef, S. (2019). The use of communication technology in the context of adolescent and Family Development: An integration of family and media theories. Journal of Family Theory \& Review, 11(4), 510-523. https://doi.org/10.1111/jftr.12350. 
Etikan, I., Musa, S. A., \& Alkassim, R. S. (2016). Comparison of convenience sampling and purposive sampling. American journal of theoretical and applied statistics, 5(1), $1-4$.

Friedman, S. L., Sigelman, C. K., Rohrbeck, C. A., \& del Rio-Gonzalez, A. M. (2017). Quantity and quality of communication during parental deployment: Links to adolescents' functioning. Applied Developmental Science, 21(4), 285-300. doi: 10.1080/10888691.2016.1207536.

Gadermann, A. M., Schonert-Reichl, K. A., \& Zumbo, B. D. (2010). Investigating validity evidence of the satisfaction with life scale adapted for children. Social Indicators Research, 96(2), 229-247. https://doi:10.1007/s11205-009-9474-1.

Gignac, G. E., \& Szodorai, E. T. (2016). Effect size guidelines for individual differences researchers. Personality and Individual Differences, 102, 74-78. https://doi.org/10.1016/j.paid.2016.06.069

Hertlein, K. M., \& Blumer, M. L. C. (2014). The couple and technology framework: Intimate relationships in a digital age. New York: Routledge.

Kementerian Pemberdayaan Perempuan dan Perlindungan Anak. (2018). Profil perempuan Indonesia 2018. Retrieved from https:/www.kemenpppa.go.id/lib/uploads/list/d9495-buku-ppi-2018.pdf.

Keijsers, L., \& Poulin, F. (2013). Developmental changes in parent-child communication throughout adolescence. Developmental Psychology, 49(12), 23012308. https://doi.org/10.1037/a0032217.

Kinkead, A., Saracostti, M., Grau, M. O., \& Caro, P. (2017). Chilean children's perspectives on their parents' work and family conflicts, tensions, and reconciliations: Preliminary gender analysis. Child Indicators Research, 10(3), 649672. https://doi:10.1007/s12187-016-9388-9.

Laursen, B., \& Collins, W. A. (2003). Parent-child communication during adolescence. In Vangelisti, A. L. (Ed.). (2003). The Routledge handbook of family communication. Routledge.

Levin, K. A., Dallago, L., \& Currie, C. (2012). The association between adolescent life satisfaction, family structure, family affluence and gender differences in parentchild communication. Social Indicators Research, 106(2), 287-305. https://doi:10.1007/s11205-011-9804-y.

Liu, W., Mei, J., Tian, L., \& Huebner, E. S. (2015). Age and gender differences in the relation between school-related social support and subjective well-being in school among students. Social Indicators Research, 125(3), 1065-1083. https://doi.org/10.1007/s11205-015-0873-1

Madianou, M., \& Miller, D. (2011). Mobile phone parenting: Reconfiguring relationships between Filipina migrant mothers and their left-behind children. New media \& society, 13(3), 457-470. https://doi.org/10.1177/1461444810393903.

McNaughton, J. (2000). Gender differences in parent child communication patterns. Retrieved January 6, 2022, from http://murphylibrary.uwlax.edu/digital/jur/2000/mcnaughton.pdf. 
McQuillan, M. E., \& Bates, J. E. (2017). Parental stress and child temperament. Parental Stress and Early Child Development, 75-106. https://doi.org/10.1007/978-3-31955376-4_4

Mesch, G. S. (2016). Parent-child connections on social networking sites and $\begin{array}{llll}\text { cyberbullying. Youth } \mathcal{E} \quad \text { Society, } & \text { 50(8), } & \text { 1145-1162. }\end{array}$ https://doi:10.1177\%2F0044118X16659685.

Moksnes, U. K., \& Espnes, G. A. (2013). Self-esteem and life satisfaction in adolescents-gender and age as potential moderators. Quality of Life Research, 22(10), 2921-2928. https://doi.org/10.1007/s11136-013-0427-4.

Nickerson, A. B., \& Nagle, R. J. (2004). The Influence of Parent and Peer Attachments on Life Satisfaction in Middle Childhood and Early Adolescence. Social Indicators Research, 66(1/2), 35-60. https://doi:10.1023/b:soci.0000007496.42095.2c.

Niu, G., Chai, H., Li, Z., Wu, L., Sun, X., \& Zhou, Z. (2020). Online parent-child communication and left-behind Children's subjective well-being: The effects of parent-child relationship and gratitude. Child Indicators Research, 13(3), 967-980. https://doi:10.1007/s12187-019-09657-z.

Oberle, E., Schonert-Reichl, K. A., \& Zumbo, B. D. (2011). Life satisfaction in early adolescence: Personal, neighborhood, School, Family, and peer influences. Journal of Youth and Adolescence, 40(7), 889-901. https://doi.org/10.1007/s10964-010-9599-1.

O'Keeffe, G. S. \& Clarke-Pearson, K. (2011) Council on Communications and Media: The impact of social media on children, adolescents, and families. Pediatrics, 127(4), 800-804. https://doi.org/10.1542/peds.2011-0054.

Padilla-Walker, L. M., Coyne, S. M., \& Fraser, A. M. (2012). Getting a high-speed family connection: Associations between Family Media Use and Family Connection. Family Relations, 61(3), 426-440. https://doi.org/10.1111/j.1741-3729.2012.00710.x

Papalia, D. E., \& Martorell, G. (2014). Experience Human Development. New York, NY: McGraw-Hill Education.

Poire, B. L. (2005). Theoretical approaches to understanding communication in the family. Family Communication Nurturing and Control in Changing World, 53-82.

Proctor, C., Linley, P. A., \& Maltby, J. (2017). Life satisfaction. Encyclopedia of adolescence, 1-12.

Rudi, J., Dworkin, J., Walker, S., \& Doty, J. (2015). Parents' use of information and communications technologies for family communication: differences by age of children. Information, Communication $\quad \mathcal{E} \quad$ Society, 18(1), 78-93. https://doi:10.1080/1369118X.2014.934390.

Satriawan, Y. (2020). Tantangan Keluarga di Era Kelaziman Baru: Kembali Bekerja di Kantor vs. Anak Belajar di Rumah. VOA Indonesia. https:/www.voaindonesia.com/a/tantangan-keluarga-di-era-kelaziman-barukembali-bekerja-di-kantor-vs-anak-belajar-di-rumah/5487243.html .

Sillars, A., Holman, A. J., Richards, A., Jacobs, K. A., Koerner, A., \& Reynolds-Dyk, A. (2014). Conversation and Conformity Orientations as Predictors of Observed Conflict Tactics in Parent-Adolescent Discussions. Journal of Family Communication, 14(1), 16-31. https://doi:10.1080/15267431.2013.857327. 
Soares, A. S., Pais-Ribeiro, J. L., \& Silva, I. (2019). Developmental assets predictors of life satisfaction in adolescents. Frontiers in Psychology, 10. https://doi.org/10.3389/fpsyg.2019.00236.

Susanti. (2013). Komunikasi dan Kelekatan Orang Tua, Kelekatan Teman Sebaya, serta Kepuasan Hidup Remaja berdasarkan Status Bekerja Ibu. http://repository.ipb.ac.id/handle/123456789/66069.

Tulk, L., Montreuil, S., Pierce, T., \& Pépin, M. (2016). Does parental work affect the psychological well-being and educational success of adolescents? Community, Work \& Family, 19(1), 80-102. https://doi.org/10.1080/13668803.2014.1002830.

Valkenburg, P. M., \& Peter, J. (2011). Online communication among adolescents: An integrated model of its attraction, opportunities, and risks. Journal of Adolescent Health, 48(2), 121-127. https://doi.org/10.1016/j.jadohealth.2010.08.020.

Vieira, J. M., Matias, M., Lopez, F. G., \& Matos, P. M. (2016). Relationships between work-family dynamics and parenting experiences: A Dyadic analysis of dualearner couples. Work $\mathcal{E}$ Stress, 30(3), 243-261. https://doi.org/10.1080/02678373.2016.1211772.

Weber, M., Ruch, W., \& Huebner, E. S. (2013). Adaptation and initial validation of the German version of the Students' Life Satisfaction Scale (German SLSS). European Journal of Psychological Assessment, 29(2), 105-112. https://doi.org/10.1027/1015$5759 / \mathrm{a} 000133$

Wohn, D. Y. (2012). The role of habit strength in social network game play. Communication Research Reports, 29(1), 74e79. http://dx.doi.org/10.1080/ 08824096.2011.639912.

Ye, M., Li, L., Li, Y., Shen, R., Wen, S., \& Zhang, J. (2013). Life satisfaction of adolescents in Hunan, China: Reliability and validity of Chinese brief multidimensional students' life satisfaction scale (BMSLSS). Social Indicators Research, 118(2), 515-522. https://doi.org/10.1007/s11205-013-0438-0

Žukauskienè, R. (2014). Adolescence and well-being. In A. Ben-Arieh, F. Casas, I. Frønes, \& J. E. Korbin (Eds.), Handbook of child well-being: Theories, methods, and policies in global perspective ( $p p$. 1713-1738). Springer. 